\title{
Reflections on the Intensive Care of 106 Acute Cervical Spinal Cord Injury Patients in the Resuscitation Unit of a General Traumatology Centre
}

\author{
J. M. Dietz, M.D., M. Bertschy, M.D., R. Gschaedler, M.D. and \\ P. Dollfus, M.D. \\ Centre Hospitalier Louis Pasteur, Colmar, France
}

\section{Summary}

This presentation deals with an 11 year survey of 106 cervical spinal cord injuries, admitted immediately after injury or during the very acute phase, to the Traumatology Resuscitation Unit of Colmar, (France). A preliminary report concerning 51 patients was published in 1979. The follow-up study concerns a further 55 cervical spinal cord injured patients admitted from fanuary 1979 to December 1984. The emphasis of our presentation concerns the frequency of some of the main complications and their attempted prevention: the haemodynamic disturbances caused by over-hydration; the prevention of haemorrhagic stress ulcers is not only by the use of specific drugs, but mainly by immediate intravenous adequate caloric nutrition. This can be associated with, or followed as soon as possible by, an adapted caloric diet, possibly by a naso-gastric tube. For serious respiratory complications, artificial ventilation even for long periods as discussed, by nasal intubation or in some patients tracheotomy.

Key words: Cervical spinal cord injury; Intensive care.

Following our preliminary study (Gschaedler et al., 1979), it appears to be of interest to give the analysis of the latest period from January 1979 to December 1984, so that 55 new cases with a cervical spinal cord lesion have been added, giving for both periods (1974-1978, 1979-1984) a total of 106 cases. The overall parameters are given in Table $\mathrm{I}$, including remarks concerning the latest period. We note in particular, that the delay for early admission, before 2 hours, is in regression of $30 \%$; between 2 and 24 hours a rise of $15 \%$; and over 24 hours, $15 \%$. Our geographical referral region has not changed and we have no correlative explanation. 
In this study, we wish to emphasise the frequency of some of the main complications and the attempts to prevent them.

The haemodynamic disturbances caused by overhydration. This can lead to an acute adult respiratory distress syndrome (ARDS) where the iatronic aspect is not negligible.

\section{Case report:}

A 29-year-old man, sustained an automobile accident at 17.00 hours, $70 \mathrm{kms}$ from Colmar, and was admitted at $22 \cdot 15$ hours. During that time i.e. 5 hours, he received 5 litres of fluid in order to 'restore his blood pressure'. On admission, the blood pressure was still $100 \mathrm{~mm} / \mathrm{Hg}$, the pulse rate $55 / \mathrm{min}$, and the rectal temperature $35.6^{\circ} \mathrm{C}$. The pulmonary capillary wedge pressure (PCWP) has risen to $22 \mathrm{~mm} / \mathrm{Hg}$ (normal approximately $8 \pm 4 \mathrm{~mm} / \mathrm{Hg}$ ) and the pulmonary artery pressure (PAP) at $31 \mathrm{~mm} / \mathrm{Hg}$ (normal at about $15 \mathrm{~mm} / \mathrm{Hg}$ ). The plasma protein level was $5.4 \mathrm{grs} . / 100 \mathrm{ml}$. X-rays of the cervical spine showed a double locked facet luxation of $\mathrm{C} 5 / 6$ (Fig. 1) associated with a complete motor spinal cord syndrome below C6 with sacral sensory sparing in S3, 4 and 5, for touch only. The luxation was immediately, and successfully, reduced under general anaesthesia, the reduction maintained by a traction with a Cones calliper. Because of instability leading to partial recurrence of the luxation during the night, he was immediately operated on by a Cloward ántero-lateral approach and a small bone graft was inserted (Fig. 2). His neurological status was unchanged. Ventilation by a naso-tracheal tube was continued. The next day, in spite of artificial ventilation with a mixture of $60 \%$ oxygen, the $\mathrm{PaO}_{2}$ was only $66 \mathrm{~mm} / \mathrm{Hg}$. The pulmonary status deteriorated rapidly resulting in ARDS in spite of a PEEP (pulmonary positive end expiratory pressure) of $10 \mathrm{~cm} / \mathrm{HO}_{2}$. The patient died of hypoxemia and hypercapnia 33 days after injury. The last X-ray (Fig. 3) is characteristic of a diffused interstical opacity, with blurred outlines. There is a minimal pneumothorax in spite of the PEEP, as well as pulmonary hepatization preventing collapse of the lung. The aetiology of ARDS is still debated and is probably of multiple origin. Overhydration was in this patient the initiating factor.

Such an irreversible complication can arise, through the lack of awareness of the consequences of attempting to re-establish the blood pressure at all costs in cervical spinal cord injury patients. The hydration of these patients, besides the consequences of the spinal cord lesion, should be monitored by central venous pressure (CVP) and/or better, by a PCWP control, which according to certain authors (Mackenzie et al., 1985) must not exceed $18 \mathrm{~mm} / \mathrm{Hg}$. The latter method is, in our opinion, a rather aggressive technique for such fragile patients, not without complications, especially in inexperienced hands. The lowering of the oncotic pressure, by loss of plasma protein, as well as by dilution, must not be overlooked.

When respiratory insufficiency requires artificial ventilation. This can be performed by naso-endotracheal intubation, using a low pressure balloon, even for a long period. Primary hasty tracheostomy can lead to severe unnecessary complications (Barois et al., 1981; Hachen, 1979). It can also prevent a surgical anterior cervical operative approach if this is indicated.

One of our patients, with a complete lesion below C8, having previously had 


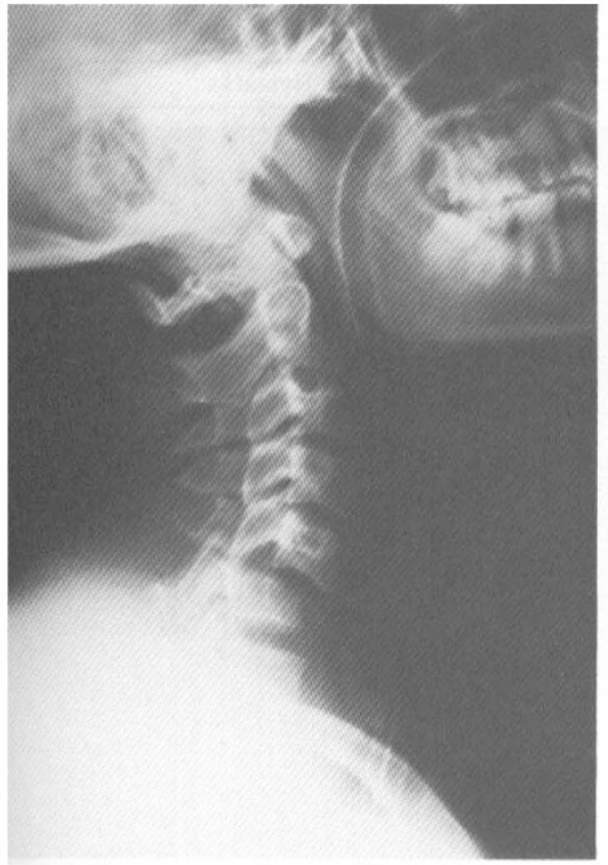

Figure 1



Figure 2

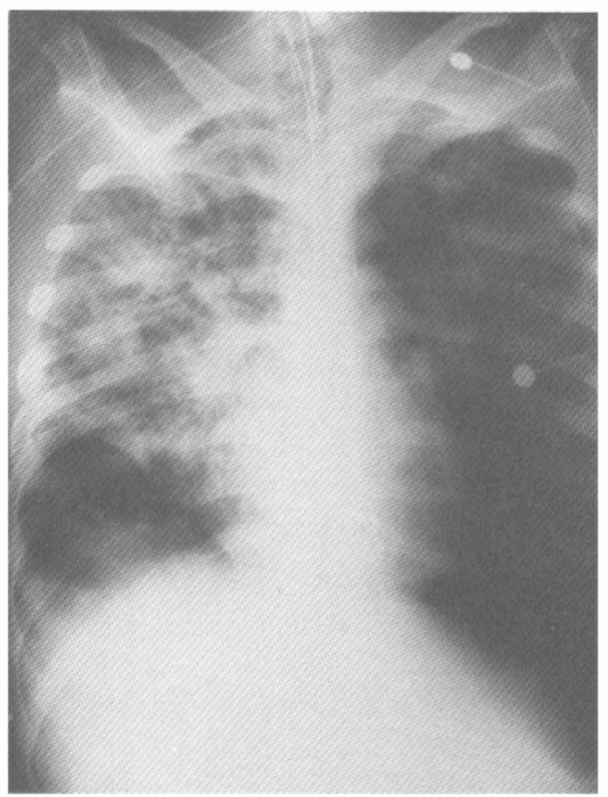

Figure 3 
Table I Results of 106 cases of acute cervical spinal patients treated between 1979-1984 in the resusitation unit of a general traumatology centre

\begin{tabular}{|c|c|c|c|}
\hline Case details & Number & $0_{0}^{\circ}$ & Remarks \\
\hline \multicolumn{4}{|l|}{ Mortality } \\
\hline Overall & 18 & 17 & stable \\
\hline S.C.I. related & 12 & 11 & stable \\
\hline Iatrogenic (A.R.D.S.) & 3 & 3 & increased \\
\hline \multicolumn{4}{|l|}{ Age } \\
\hline from 15 to 25 years & 31 & 29 & mainly traffic accidents \\
\hline from 25 to 35 years & 22 & 20 & \\
\hline from 35 to 45 years & 9 & 9 & \\
\hline from 45 to 55 years & 12 & 11 & \\
\hline from 55 to 65 years & 9 & 9 & \\
\hline more than 65 years & 23 & 22 & \\
\hline \multicolumn{4}{|l|}{ Aetiology } \\
\hline Domestic (mainly falls) & 19 & 18 & \\
\hline Traffic accident & 54 & 51 & \\
\hline Fire arm wounds, assaults & 3 & 4 & \\
\hline Falls from trees & 12 & 11 & \\
\hline Sport & 2 & 1 & \\
\hline Attempted suicide & 2 & 2 & \\
\hline Industrial injuries & 14 & 13 & \\
\hline \multicolumn{4}{|l|}{ Sex } \\
\hline Male & 85 & 80 & \\
\hline Female & 21 & 20 & \\
\hline \multicolumn{4}{|l|}{ Delay of Admission } \\
\hline Less than 2 hours & 48 & $45(-30)$ & \\
\hline from 2 to 24 hours & 39 & $37(+15)$ & \\
\hline more than 24 hours & 19 & $18(+15)$ & \\
\hline \multicolumn{4}{|l|}{ Reduction } \\
\hline Orthopaedic & 75 & 71 & \\
\hline Orthopaedic (under G.A.) & 10 & 9 & \\
\hline Surgical & 21 & 20 & \\
\hline \multicolumn{4}{|l|}{ Ventilation } \\
\hline Number & 33 & 31 & stable \\
\hline Intubations & 31 & 29 & stable \\
\hline Tracheostomies & 2 & 2 & (one transfer in 1979) \\
\hline \multicolumn{4}{|l|}{ Average ventilation 16 days } \\
\hline \multicolumn{4}{|l|}{ 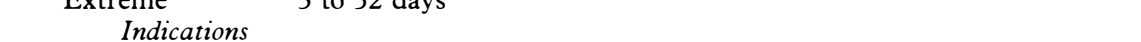 } \\
\hline S.C.I. & 21 & 65 & \\
\hline Post-operative & 2 & 6 & \\
\hline Associated lesions & 10 & 29 & \\
\hline \multicolumn{4}{|l|}{ Associated lesions } \\
\hline Polytraumatised & 9 & 8 & head + thorax + limbs \\
\hline Head injuries + coma & 8 & 7 & \\
\hline Multiple fractures & 8 & 7 & \\
\hline Thorax & 10 & 9 & \\
\hline Additional distal spine injuries & 12 & $11(+14)$ & \\
\hline Total & 47 & 44 & stable \\
\hline \multicolumn{4}{|l|}{ Complications } \\
\hline A.R.D.S. & 3 & 3 & \\
\hline Intercurrent urinary infections & 18 & 17 & stable \\
\hline Gastro-intestinal haemorrhages & 6 & 6 & stable, less severe \\
\hline Pulmonary emboli & 3 & 3 & (last in 1977) \\
\hline \multicolumn{4}{|l|}{ Stay in Intensive Care Unit } \\
\hline Average $\quad 11$ days & & & \\
\hline 2 to 52 days & & & \\
\hline \multicolumn{4}{|l|}{ Parenteral Nutrition } \\
\hline Average & $3 \cdot 3$ & & \\
\hline S.C.I. alone & $3 \cdot 0$ days & & \\
\hline Associated lesions & 3.7 days & & \\
\hline
\end{tabular}


Table II Neurological results by

Frankel's classification system

\begin{tabular}{ccccc}
\hline $\mathrm{AA}$ & $\mathrm{AB}$ & $\mathrm{AC}$ & $\mathrm{AD}$ & $\mathrm{AE}$ \\
19 & 7 & 0 & 1 & 0 \\
$\mathrm{BA}$ & $\mathrm{BB}$ & $\mathrm{BC}$ & $\mathrm{BD}$ & $\mathrm{BE}$ \\
0 & 6 & 4 & 9 & 0 \\
$\mathrm{CA}$ & $\mathrm{CB}$ & $\mathrm{CC}$ & $\mathrm{CD}$ & $\mathrm{CE}$ \\
0 & 0 & 2 & 18 & 7 \\
$\mathrm{DA}$ & $\mathrm{DB}$ & $\mathrm{DC}$ & $\mathrm{DD}$ & $\mathrm{DE}$ \\
0 & 0 & 0 & 0 & 15 \\
$\mathrm{EA}$ & $\mathrm{EB}$ & $\mathrm{EC}$ & $\mathrm{ED}$ & $\mathrm{EE}$ \\
0 & 0 & 0 & 0 & 0 \\
\hline
\end{tabular}

a tracheotomy before transfer in February 1979, is still in 1985, in the same state because of tracheostenosis and malacia. The price to pay for this therapy is an experienced medical and nursing staff, around the clock, familiar with all the technical aspects of artificial ventilation and the technique of naso-tracheal intubation (humidification, asepsis, extubation and re-intubation procedures, etc.). We do not have the experience of a secondary deliberate tracheotomy required for patients with high cervical lesions who will depend on long lasting or permanent artificial ventilation. (Our experience in naso-tracheal intubation, since 1970, in other traumatic patients, than cervical spinal cord injuries, includes 573 patients who required intubation for from 3 to 87 days. Four complications occurred with this technique: three tracheostenoses and one tracheomalacia. This is a complication rate of $0 \cdot 7^{\circ}$. A male patient aged 70 years who died after 87 days of intubation died from a vascular cerebral lesion. Since 1970, 9 tracheotomised patients were treated, four were transferred already tracheotomised from from elsewhere. In this very small series, two patients had tracheostenoses, and two had severe haemorrhagic complications, giving a percentage of no statistical value, of $44 \%$.

In concluding our remarks on ventilation, we would like to claim that nasotracheal intubation is to be preferred to tracheotomy for the expected weaning from the respirator. But tracheotomy becomes necessary each time there is a serious doubt about the return of spontaneous adequate ventilation, mainly because of the high level of the lesion.

Prevention of haemorrhagic stress ulcers. These are more frequent in patients with cervical lesions (Zäch and Seiler, 1977; Hachen et al., 1981; El Masri et al., 1983). We do not only use anti $\mathrm{H} 2$ receptor drugs such as Cimitidine or Ranitidine but introduce immediate intravenous fluids and adequate nutrition (30-40 cal. $/ \mathrm{kg}$ and $0.20 \mathrm{grs}$ of Nitrogen $/ \mathrm{kg}$ ). This nutrition must be brought with the least fluid volume as possible, not exceeding 1.5 litres daily. Parenteral nutrition, averaging 3 days in our two series, must, in our opinion, be follcwed as soon as possible by constant adapted enteral feeding by a naso-gastric tube if the patient is unable to be fed by mouth (as always occurs with naso-endotracheal ventilated patients).

The neurological diagnosis of severe cervical lesions, below $\mathrm{C} 4$, in an unconscious patient (coma stage I to III) has been discussed in our previous article. We have noted in unconscious patients that repeated noxious stimuli 
over the precordial area (by repeated pricking with a needle or pinching of the skin) can in the case of an intact spinal cord, or in a very incomplete spinal cord lesion, raise the heart rate between 20 to $30 \%$. In a complete cervical lesion (the clinical lesion having been proved afterwards) these changes did not occur (nevertheless this needs to be scientifically assessed).

The evolution of the neurological lesion. This is given in Table II according to Frankel's classification system. We have noticed no difference between the operated and the non-operated group of patients, although the number of operations have been on the increase since our last serie.

Corticosteroids. In an attempt to prevent the extension of the spinal cord lesion, or its oedema, these have been definitely abandoned since their value has not been proved in our Mulhouse-Colmar series presented in 1980 (Philippi et al.). Their hazardous side effects are well known. We have no experience of the use of Thyrotropin-Releasing Hormone (TRII) and Naloxone (Faden et al., 1983), nor of clinical use of the experimental megadose cortico-steroid injection proposed as a preventive therapy immediately after the accident (Faden et al., 1984).

Prophylactic subcutaneous Heparin is now used 8 hourly and in the last series doses have been daily adjusted to the Howell test, as well as positioning the patient slightly head down so as to accelerate the venous return (incidentally no clinical signs of emboli have been observed since 1977).

In conclusion we emphasise that the greatest care should be provided for these fragile patients. Their immediate transfer to a specialised intensive care unit must again be stressed. Overhydration should at all costs be avoided, proper nutrition and metabolic management should be started as soon as possible. Tracheotomy should be avoided. We would also like to pay a tribute to the outstanding work of Jacqueline Claus-Walker (1977).

\section{Résumé}

106 lésions médullaires cervicales post-traumatiques ont été analysées. La première série portant sur 51 lésions a déjà été publiée en 1979. Les réanimations portant sur 55 lésions sont rapportées dans la 2e série de 1979 à fin 1984. Les auteurs insistent particulièrement sur l'importance des perturbations hémodynamiques pouvant aboutir à un syndrome de détresse respiratoire de l'adulte (SDRA). Une observation est donnée. Par ailleurs, les méthodes préventives de l'hémorragie digestive sont discutées, l'alimentation parentérale et entérale instituée aussitôt que possible semble être de importance dans cette prophylaxie en association avec les médications à visée antagoniste des récepteurs $\mathrm{H} 2$ à l'Histamine. Enfin, en cas d'insuffisance ventilatoire, l'intubation naso-trachéale devrait toujours être préférée à la trachéotomie (moins de $1^{\circ}$ o dans notre série) dès lors qu'il existe un espoir raisonnable de sevrage du respirateur.

\section{Zusammenfassung}

106 Halsrückenmarkschädigungen werden analysiert. 51 davon wurden schon im Jahre 1979 veröffentlicht. 55 neue Läsionen werden in einer Zweiten Serie untersucht. Erstens weisen die Autoren besonders auf das Risiko der akuten Ateminsuffizenz hin, die durch erhebliche Infúsionen (die manchmal zur Herstellung des Blutdruckes verabreicht werden) verursacht werden kann. Bericht über ein Fall der lethal ausging. Zweitens werden verschiedene Methoden zur Vorbeugung der Gastrointestinalenstressblutungen besprochen. Im Wesentlichen werden frühzeitige parenterale und enterale adequate Ernährung sowie Verabreichungen von Cimetidin oder Ranitidin empfohlen. Endlich, sind die Autoren der Meinung dass wenn künstliche Beatmung unentbehrlich wird, die naso-tracheale Intubation bevorzugt werden soll. Die Tracheotomie sollte nur dann in Frage kommen, wenn gar keine Hoffnung zur Spontanatmung besteht, so z.B. wenn das Niveau der kompletten Schädigung auf der Höhe der allerersten Halwirbeln steht. 


\section{References}

Barois A, Gschaedler R, Dollfus P 1981 Le traitement médical d'urgence. La Paraplégie (Maury M.) (pp. 49-63) Flammarion Medecine-Sciences, Paris

Ćlaus-Walker J, Carter RE, Di Ferrante NM, Singh J 1977 Immediate endocrine and metabölic consequences of traumatic quadriplegia in a young woman. Paraplegia 15:202-208

FADEN AT, JacoBs TP, SMith MT, HoladAY JW 1983 Comparison of thyrotropin-releasing hormone (TRH), naloxone, and dexamethasone treatments in experimental spinal injury. Neurology 33:673-678

Faden AI, Jacobs TJ, Patrick DF, Smith MT 1984 Megadose corticosteroid therapy following experimental traumatic spinal injury. Journal of Neurosurgery 60:712-717

Frankel HL 1970 Tracheal stenosis following tracheostomy. Paraplegia 8: 172-176

Gschaedler R, Dollfus P, Mole JP, Mole L, Loeb JP 1979 Reflections on the intensive care of acute cervical spinal cord injuries in a general traumatology centre. Paraplegia 17:58-61

HACHEN HJ 1977 Idealised care of the acutely injured spinal cord in Switzerland. The Journal of Trauma 17:931-936

HaChen HJ, Barois A, Gschaedler R 1981 Les complications cardiovasculaires. La Paraplégie (Maury M.) (pp. 130-132). Flammarion Medecine-Sciences, Paris.

MACKenZie CF, Shin B, KRishnaprasad D, MCCormaCK F 1985 Assessment of cardiac and respiratory function during survey on patients with acute quadriplegia. Journal of Neurosurgery 62:843-849

El Masri W, Cochrane P, Silver JR 1983 Gastrointestinal bleeding in patients with acute spinal injuries. Injury: The British Journal of Accident Surgery 14: 162-167.

Philippi R, Kuhn W, Zach GA, Jacob-Chia D, Dollfus P, Mole JF 1980 Survey of the neurological evolution of 300 spinal cord injuries seen within 24 hours after injury. Paraplegia 18:337-346

ZACH GA, SEILER W 1977 Lésion de la muqueuse gastroduodénale et choc spinal. Annales de Médecine Physique 20:340-342 